\title{
In the Limelight? Interpreters' Visibility in Transborder Interpreting
}

\author{
ABSTRACT
}

This paper explores photographs that were taken along the Austrian and Slovene border between 2015 and 2018 as ethnographic records of a specific field of interpreting. The photographs show interpreters who helped bridge communication barriers in situations when the mass displacement of refugees from the Middle East resulted in an increased demand for interpreters for a range of languages that had previously not been as sought after. The photographs come from a corpus of pictures and accompanying texts that were compiled through a picture search in digital media. Drawing on the constructs of (in)visibility and bodily semiotics, a set of chosen examples is analysed qualitatively, using a visually oriented approach to examine interpreters' positionality and agency in transborder humanitarian interpreting. The results suggest a high degree of interactional agency and visibility, but less social visibility.

Keywords: public service interpreting, humanitarian interpreting, visual analysis, interpreter agency, visibility

\section{V središču pozornosti? Vidnost tolmačev in tolmačk pri čezmejnem tolmačenju}

\section{IZVLEČEK}

$\mathrm{V}$ prispevku analiziramo fotografije, posnete vzdolž avstrijske in slovenske meje v letih od 2015 do 2018, ki predstavljajo etnografski posnetek specifičnega tolmaškega okolja v zelo raznolikem kontekstu institucionalne in humanitarne interakcije. Na posnetkih so prikazani tolmači in tolmačke, ki so pomagali premagovati komunikacijske ovire $\mathrm{v}$ času, ko se je zaradi obsežnejših begunskih migracij iz Srednjega Vzhoda povečalo povpraševanje po tolmačenju $\mathrm{v}$ različnih situacijah ob in na nacionalnih mejah za najrazličnejše jezike, po katerih pred tem ni bilo povpraševanja. Fotografije izvirajo iz korpusa fotografij in pripadajočih besedil, ki smo ga sestavili z iskanjem fotografij v digitalnih medijih. Na podlagi koncepta (ne)vidnosti in semiotike telesa $\mathrm{v}$ prispevku kvalitativno analiziramo nekaj izbranih fotografij z uporabo vizualno-naravnanega pristopa, kar omogoča proučitev pozicionalnosti in angažiranosti tolmačev in tolmačk v okolju čezmejnega humanitarnega tolmačenja. Rezultati pričajo o visoki stopnji angažiranosti in vidnosti v interakciji ter o nižji stopnji socialne vidnosti.

Ključne besede: tolmačenje za potrebe skupnosti, humanitarno tolmačenje, vizualna analiza, tolmaška angažiranost, vidnost 


\section{Introduction}

A UNHCR handbook on training interpreters in asylum proceedings (UNHRC 2015, 2018) includes a quotation from a non-trained interpreter on its title page: "It is a fiction that I am neutral and invisible." This remark addresses two multi-faceted concepts that are much present in interpreting (and translation) literature, and, as confirmed by the quotation, also among practitioners: neutrality and (in)visibility. The concept of visibility, which holds a prominent position in the extract, also forms the starting point for this contribution, which explores photographs that were taken along the Austrian and Slovene border between 2015 and 2018 as ethnographic records of a specific field of interpreting in the context of institutional and humanitarian interaction. The photographs show individuals who supposedly helped bridge communication barriers. In the wake of the mass displacement of refugees from the Middle East, who made their way by various routes across Europe in the mid-2010s, the demand for interpreters increased, especially for rarer $^{1}$ non-European languages which had not been in high demand before. The term interpreter as we use it in this contribution refers to what are called community interpreters (public services interpreters, dialogue interpreters, liaison interpreters), who may be either trained or untrained interpreters. The profile of interpreter should be distinguished from that of intercultural mediator (also mother-tongue mediator, cultural mediator or integration assistant), whose task is to assist and support migrants (see Pokorn 2020, 10-11, Pokorn et al. 2020, and Pokorn and Mikolič Južnič 2020 for a more detailed outline of these occupational profiles).

Our countries, Austria and Slovenia, which have one joint border that lies along the Western Balkans route, also had to cope with increased demand for interpreting. It was our impression in the wake of these developments that it was not only language barriers (see Federici 2020) and the often-urgent need for interpreters that were more present in the media than before, but that interpreters were also more often shown in photographs and thus were literally more visible. It is not our intent to quantify this impression, and neither would our corpus allow for such an assessment, but we take Fernández-Ocampo and Wolf's (2014a, 72) suggestion that photographs are an "ethnographic record" of a field, as a starting point to discuss interpreters' visual and visible positionality in the specific field of transborder interpreting. ${ }^{2}$ We use the concept of visibility to analyse photographs of interpreters in action in close vicinity to the Austrian-Slovene border between 2015 and 2018 (border control stations, reception centres) to take a glimpse into interpreting practice. Our overarching research question is what photographs such as those chosen for this contribution may tell us about the tangible physical visibility, positionality and agency of interpreters/mediators in such specific situations. Based on what can be gleaned from a

\footnotetext{
In interpreting literature, languages that are not much sought-after in terms of the market are often referred to as languages of limited diffusion, or, in a less neutral register, as exotic or migrant/refugee languages. This labelling, however, depends on the user's perspective: in an interpreting context, a language that is rare in one country may have a large number of speakers in other environments, which also holds true for some of the languages that were in high demand in the situations shown in the photographic examples we use (e.g., Dari, Farsi and Arabic).

2 The "pictorial turn", as it was coined by Mitchell (1992), brought about a reorientation towards visual analysis. A number of authors have adopted such approaches in interpreting studies, but there does not yet seem to exist an agreed analytical or methodological framework for conducting such visually oriented analyses (see for instance Fernández-Ocampo and Wolf 2014b; Zimányi 2015; Baigorri-Jalón 2016; Torresi 2017).
} 
review of the public service interpreting (PSI) literature, we hypothesize that interpreters are physically visible in many of the photographs and that the photographs will show instances of open agency and involvement.

Photographs can play an important role in addressing dimensions of visibility because they generate meaning "on a non-linguistic level" (Breckner 2010, 107; our translation" and "add something to the world, a visible object of a view which would not exist without this picture or these kinds of pictures" (Breckner 2010, 107). Photographs, as objects of study, allow for a specific perspective, which can only be consciously perceived after close and "reflexive attention" (Breckner 2010, 94). This conscious perception results in social visibility and, theoretically, increased social recognition. Following Brighenti, recognition is a form of social visibility that may also have important consequences for the relationship between a minority group and a majority $(2007,329)$, which seems particularly relevant for a field like PSI, where one party in an interpreter-mediated encounter belongs to a marginalized clientele, often the "losers of globalisation" (Prunč 2017, 25), with low social, economic and cultural status, while the other (institutional) party often has a higher status as a member of the majority group, and where interpreters, who may also have a minority background, may "fall prey to this powerlessness" (Prunč 2017, 25).

Visibility is also an important social category that is shaped by information and communication technologies:

[...] As communication technologies enlarge the field of the socially visible, visibility becomes a supply and demand market. At any enlargement of the field, the question arises of what is worth being seen at which price - along with the normative question of what should and what should not be seen. These questions are never simply a technical matter: they are inherently practical and political. (Brighenti 2007, 327)

This practical and political dimension of visibility is also closely linked, though not in a linear fashion, with various dimensions of social recognition: "[t]hresholds of visibility come into play here: there is a minimum and a maximum of what we may call 'fair visibility' - regardless of the fairness criteria we want to adopt. Below the lower threshold, you are socially excluded" (Brighenti 2007, 329-30). Once an individual enters the upper zone of fair visibility, however, they are in a zone of "supra-visibility, or super-visibility, where everything you do becomes gigantic" (Brighenti 2007, 331). The social visibility of an individual or a group of people can thus be lowered or increased through visual addressing, which makes photographs an interesting tool for studying a specific field.

We will outline the geopolitical background of the context in which the photographs we analyse were taken, before discussing various dimensions of interpreter visibility, which will be used for our analysis of a sample of four photographs from our corpus. Corpus compilation and our methodological approach are described in section 4 , which is followed by our analysis of the chosen set of photographs.

All quotations from German-language publications are the authors' translations unless otherwise specified. 


\section{Geopolitical Context and Research Coverage}

What has negatively been portrayed as the European refugee crisis in the mass media is a situation that started around 2013 and peaked in 2015/2016, where large groups of refugees of varied origin travelled by many routes and across various states in the Near East and Europe to reach destination countries in Europe, a movement which tested European reception and asylum systems (UNHCR 2016, 34). The major source countries for arrivals in the Mediterranean in 2015 were Syria, Afghanistan and Iraq (UNHCR 2016, 35). In peak times, the groups of people on their way towards the north were so numerous that many countries no longer saw fit to impose any kind of border controls, and large groups crossed the borders between countries unimpeded. After governments tried to regain control by stepping up border controls and setting up fences and temporary camps to steer these movements and restrict access, the situation often still remained challenging for some time, with transit camps and fenced-off areas, for instance at the major border crossing between Austria and Slovenia, Spielfeld/Šentilj. Management was often sustained only through the help of volunteers and humanitarian organizations (Mokre 2015), and communication barriers were also often bridged through the help of volunteer translators/interpreters. Studies on the role of interpreters in these contexts are scarce ${ }^{4}$. From what little is known, many of these volunteer interpreters were highly committed and driven by the need to help (see, for instance, Wagner 2017), though media reports also indicated cases of mismanagement where interpreters were given considerable leeway (Mokre 2015, 29-44; Pišek and Šučur 2016). Since then, many countries have closed off their borders and established stronger control, and refugees have become stranded in camps in different countries with often inhumane conditions.

On an international level, the literature on the positionality of interpreters in such transnational transit zones also remains scarce. Only a small number of contributions seem to have addressed issues of interpreting in relation to these more recent European developments in more depth (Todorova 2017; Cemerin 2019; Rudvin and Carfagnini 2020; Todorova 2020; also see Declercq and Federici 2019)..$^{5}$ Besides, organizations such as Translators without Borders (2017 a, b) have also addressed the topic and prepared "field guides" for "humanitarian interpreting and cultural mediation" (for a critical review of volunteerism and activism in this context, see Piróth and Baker 2019). The kind of interpreting that takes place in such transnational conflict situations has produced a number of new labels, such as "interpreting in conflict zones" (Ruiz 2020), "humanitarian interpreting" (Delgado-Luchner and Kherbiche 2018), or "shuttle interpreting" (Todorova 2017); the demarcation lines between these still seem to be hazy, however, and, depending on the concrete situation, the field shows parallels to fields of extra-court legal interpreting, such as asylum interpreting.

\footnotetext{
There are a small number of studies dealing with communication problems arising from the mass displacement of refugees from a Slovene perspective, focusing, e.g., on mediation strategies used by migrants (Pokorn and Čibej 2018a, 308-27), commonly used communication strategies of asylum seekers (Pokorn and Čibej 2018b, 288-307) and community interpreting in various settings (Morel and Gorjanc 2016).

5 For studies on an extra-European context, see for instance, Delgado-Luchner and Kherbiche (2018) on Kenya, or Wallace and Hernandez (2017) on the situation along the Texan border.
} 


\section{Dimensions of Interpreter Visibility}

We will study interpreters' visibility on three levels. Our first dimension of visibility will be interpreter' tangible physical visibility, and how this category is discernible in the photographs we use as examples. Secondly, we will address visibility as an interactionrelated category to take a look at what the photographs in our corpus may tell us about the degree of interpreter "agency" (Kinnunen and Koskinen 2010). For this, we will make use of Kalverkämper's (2008) observations on bodily semiotics and his typology of different types of bodily communication and posture used by interpreters. Our third dimension will address interpreters' social visibility and recognition.

\subsection{Physical Visibility}

A first dimension of visibility is interpreters' concrete physical visibility, which is particularly tangible in the field of PSI, where there is often little distance, at least in face-to-face interpreting, ${ }^{6}$ between interactants. When taking a first look at interpreters in photographs, the initial step will be to ascertain who is who: who of those framed in a photograph are interpreters, what are their relations to other individuals shown, and how is their supposed function signalled to users? We assume that in spite, or perhaps because, of the chaotic situations in which interpreters had to work in the examples we use, they will have made use of or been given some kind of external signage (vests, badges or signs) to make them distinguishable from others.

\subsection{Interactional Visibility}

The introductory quotation is multi-faceted in that it mixes two complex concepts, and it may remind readers of Metzger's (1999) deconstruction of the "myth of neutrality": It links the concept of neutrality, as a central tenet of codes of ethics and a maxim that is also conveyed in interpreter education, to the concept of visibility. Neutrality, in its literal sense, means that interpreters should not take sides but should be impartial, although as Harrington holds $(2004,110)$, from a more linguistic perspective, "it can be used to describe the extent to which an interpreter might remain faithful to the content and form of each utterance" and can thus be linked to the old debate about faithful or free translation and the bon mot of "traduttore - traditore". Recently, the construct of impartiality has been expanded to concepts such as "multipartiality" (Kadrić in print), which seek to underline that interpreters have an equal responsibility towards all primary participants, even though, as convincing as this may seem, examples from the field of PSI suggest that this will not always be feasible for moral/ethical reasons (Pöllabauer and Topolovec 2020). (In)visibility, with a focus on interpreting, has been linked to the role and the degree of agency interpreters have and perform in a given situation. As a metaphor, invisibility has been used if interpreters are viewed as mere "conduits" (Roy 1993) and mechanistic language converters, a view that has been particularly prominent, and sometimes vociferously supported, in conference interpreting (Angelelli 2004b, 20), where interpreters are viewed as invisible as long as they produce "fluent", elegant renditions and become visible only if they intervene (Torikai 2009,

The situation is different in distance interpreting, yet issues of physical visibility are equally important. 
158). The fact that, for instance in monological situations such a simultaneous conference interpreting, interpreters in their booths are indeed invisible (or minimally visible) to their audience, can explain why such metaphors have come into use (Torikai 2009, 158) and are still popular among some representatives of this faction (Angelelli 2004b, 79), though more recent studies have shown that conference interpreters also view themselves more broadly as "facilitators of communication" or "intermediaries" (Zwischenberger 2009, 247; see also Diriker 2004). With an increased focus on dialogical situations in court and in different fields of PSI, the invisibility metaphor has lost its persuasiveness, since interpreters are physically visible in dialogical face-to-face situations through their sheer presence in close proximity to the primary interactants, and occasionally heavily involved in situations. Starting with ground-breaking studies such as those by Wadensjö (1998) or Metzger (1999), many studies have since shown that interpreters in such fields adopt a more visible participatory role (Angelelli 2004a, 16) in explicitly and implicitly coordinating talk (Wadensjö 1998, 108-10). As Martínez-Gómez claims, the maxim of invisibility "has $[\ldots]$ started to be deconstructed in favour of the image of interpreters as active third parties who exert their agency in order to help to achieve interactional goals, be it through the organization of talk or by participating with their own voices" $(2015,189)$. Here the aforementioned agency concept comes into play, defined as the "the willingness and ability to act" (Kinunen and Koskinen 2010, 165). Angelelli (2004a) views interpreters' agency along a "visibility continuum", with "minor visibility" if interpreters are "co-owners" of texts and "major visibility" if they are original authors and "owners of texts" (see also Zhan and Zeng 2017). If visibility is limited to coordinating talk (Wadensjö 1998), interpreters may still be impartial in that they are equally aligned with all parties. If, however, visibility means taking sides or advocating (Barsky 1996) on behalf of one party, interpreters are no longer in a position to serve as neutral intermediaries. And in more extreme situations, where interpreters feel morally obliged to become involved (CamaydFreixas 2013), visibility may even entail the conscious decision to forfeit impartiality to protect the interests of the weaker party, as advocated by some. To what degree such an advocacy position, where the lines between interpreting and mediation seem blurred, is accepted, has however, been subject to controversy (Pöllabauer 2015).

We aim to analyse how interactional visibility is reflected in examples from our corpus and will use three categories of Kalverkämper's typology of interpreters' bodily agency and types of posture (2008, 107-48). Kalverkämper underlines the primacy of the "communicative body" by deconstructing one of the most famous biblical sentences: "In the beginning, there was the body" (2008, 78). Based on the assumption that nonverbal communication plays a central role in communication, he links aspects of visibility with "types of posture". His category of the "political body", where interpreters represent specific interests, is related to the view that interpreters have the power to intervene, interfere, or correct $(2008,114)$. Interpreting may be viewed as a political act if interpreters side with one party $(2008,130)$. The category of the "functional body", where in his view interpreter "co-act" $(2008,131)$ relates to the serving role of interpreters, not in the sense of submissive service, but in the sense of functioning as professional intermediaries in a given situation between other interactants. The prefix con-is used to account for the more traditional view of the role of interpreters outlined above, which, according to Kalverkämper, is still upheld particularly by conference interpreters, who tend to 
view themselves and their bodily communication as instruments (con-actants) in a situation $(2008,134)$. Interactivity is linked with Kalverkämper's third category of the "engaged body", where interpreters engage as helping agents $(2008,146-48)$; in such a function, interpreters truly inter-act with others but may sometimes also serve as helpers and highly committed active agents.

\subsection{Social Visibility}

(In)visibility, as a concept, has also been used to indicate that in translation the influence of translators on text design has often been ignored or underestimated, especially if target texts are aligned to the target cultural conventions ("domesticated") and are fluent translations, to be read as if they were originals (Venuti 2008). If translators produce translations that are domesticating, they are less visible, and their work, according to Venuti, also often finds little recognition (e.g., translators are often not even mentioned). ${ }^{7}$ In this sense, (in) visibility is linked with the social recognition of translators. This dimension of visibility has become a central topic in critical media studies, which address the links between visibility and recognition and how these processes shape the granting and gaining of access to economic, social, and cultural resources (Thomas et al. 2017, 11). With respect to interpreting, visibility can also be linked to recognition: for Takeda, social recognition is an important facet of interpreters' visibility and involves "seeing" the interpreter in a metaphoric sense: "[...] the 'seeing' is performed by all parties, whether present or not, and visibility is determined by whether these parties note the action or existence of interpreters, either positively or negatively" (Takeda 2014, 151). Wolf and Fernández-Ocampo (2014, 4) also link the study of pictures from a range of war contexts with the social recognition of interpreters in their approach to a visual perspective: "Being produced and consumed by agents external to the interpreting profession, visual documents and representations of interpreters cast light on the visibility of the translator. However, they also show how interpreting overlaps with other professional and symbolic activities". PSI is one of those fields of interpreting where interpreters have little social recognition in the form of symbolic capital (Prunč 2017). It is thus interesting to study what kinds of social visibility can be read into the examples that are studied in this contribution under section 5 . In section 4, below, we will outline our corpus and methodological approach.

\section{Corpus Compilation and Methodology}

Following Brighenti's assumption that mass media can be viewed as "high-visibility places endowed with the quality of conferring visibility to the people who join them" (Brighenti $2007,332)$, we decided to use the Internet as a reservoir of digital mass media to compile our corpus. We conducted an online search via the Google web browser ${ }^{8}$ in November 2020, with the picture search function to narrow results (only hits from the first results page

Venuti relates to Schleiermacher's view of foreignizing vs. domesticating translation strategies, though his views differ from Schleiermacher in that he sees foreignizing as a dissident practice that could help translators to be more visible, while Schleiermacher sees it as a form of enriching the target cultural codes (Prunč 2012, 311).

8 The surprisingly high number of results that were yielded through a search via a widely used commercial browser such as Google, made us change our initial plans to subsequently expand our search to browsers that are less commercial and more specific picture search engines. This, however, might be a suggestion for similar projects with a broader scope. 
were included). The results included hits from different digital media (newspapers, blogs, forums, journals and website text). A previously agreed set of German and Slovene search words (incl. truncation and Boolean operators) was used.?

The following exclusion criteria were used to narrow the hits: 1) material dated before $2013,2)$ situations that are most probably not interpreting situations, and 3) material addressing the situation in countries other than Austria or Slovenia. Criteria to assess the eligibility of those records that passed the first screening were that at least one of the individuals shown in the photograph could be assumed to be an interpreter because of 1) visible signs (badges, vests), 2) picture captions, 3) accompanying text, or 4) picture content (the "situation"). Following the exclusion of records based on these exclusion criteria, the final corpus included a total of 43 photographs, four of which were analysed in more detail in this contribution. Two were chosen from the German records and two from the Slovene. Our criterion for selection of this sample was that the situations shown be as diverse as possible. The flowchart ${ }^{10}$ in Figure 1 documents the search process and inclusion/exclusion criteria.

Our analysis of four examples from our corpus comprises two steps: 1) description of the factual context, if available at all, for the chosen photographs (date of publication, medium, photographer, captions and any additional information available); 2) description of the interpreters' agency and alignment to other interactants as visible from what is shown in these photographs based on the dimensions of visibility outlined above. Our interpretations are complemented, if available, by information and comments from the co-texts in which the photographs are embedded. Formal written permission for the reproduction of all the photographs was obtained from the copyright holders.

9 German search phrases: "Dolmetschen/Dolmetscher + Grenze" [interpreting/interpreter + border]; "Übersetzen/ Übersetzer + Grenze" [translation/translator + border]; "Dolmetschen/Dolmetscher + Flucht" [interpreting/ interpreter + displacement]; "Übersetzen/Übersetzer + Flucht “ [translation/translator + displacement]; "Dolmetschen/ Dolmetscher + Flüchtling(e)" [interpreter + refugee(s)]; “Übersetzen/Übersetzer + Flüchtling(e)" [translation/ translator + refugee(s)]; "Dolmetschen/Dolmetscher + Asylwerber" [interpreting/interpreter + asylum seekers]; Slovene search phrases: "tolmačenje/tolmač + meja” [interpreting/interpreter + border]; "prevajanje/prevajalec + meja" [translation/translator + border]; "tolmačenje/tolmač + mejni prehod" [interpreting/interpreter + border crossing]; "prevajanje/prevajalec + mejni prehod" [translation/translator + border crossing]; "tolmačenje/tolmač + beg" [interpreting/interpreter + displacement]; "prevajanje/prevajalec + beg” [translation/translator + displacement]; "tolmačenje/tolmač + begunec/begunci" [interpreting/interpreter + refugee(s)]; "prevajanje/prevajalec + begunecl begunci” [translation/translator + refugee(s)]; "tolmačenje/tolmač + migrant/migranti” [interpreting/interpreter + $\operatorname{migrant}(\mathrm{s})]$; "prevajanje/prevajalec + migrant/migranti” [translation/translator $+\operatorname{migrant}(\mathrm{s})]$; "tolmačenje/tolmač + prebežnik/prebežniki” [interpreting/interpreter + fugitive(s)]; “prevajanje/prevajalec + prebežnik/prebežniki” [translation/translator + fugitive(s)]; “tolmačenje/tolmač + prosilec za azil/prosilci za azil” [interpreting/interpreter + applicant(s) for asylum]; "prevajanje/prevajalec + prosilec za azil/prosilci za azil” [translation/translator + applicant(s) for asylum]; "tolmačenje/tolmač + iskalec azila/iskalci azila" [interpreting/interpreter + asylum seeker(s)]; "prevajanje/ prevajalec + iskalec azila/iskalci azila" [translation/translator + interpreter + asylum seeker(s)]. (Owing to wording and the availability/frequency of synonyms, the Slovene list of terms is longer than the German.)

10 The flowchart (Moher et al. 2009) is an adapted version of the PRISMA (Preferred Reporting Items for Systematic Reviews and Meta-Analyses) flow diagram that, apart from reviews and meta-analyses, may also be used for other types of research. 


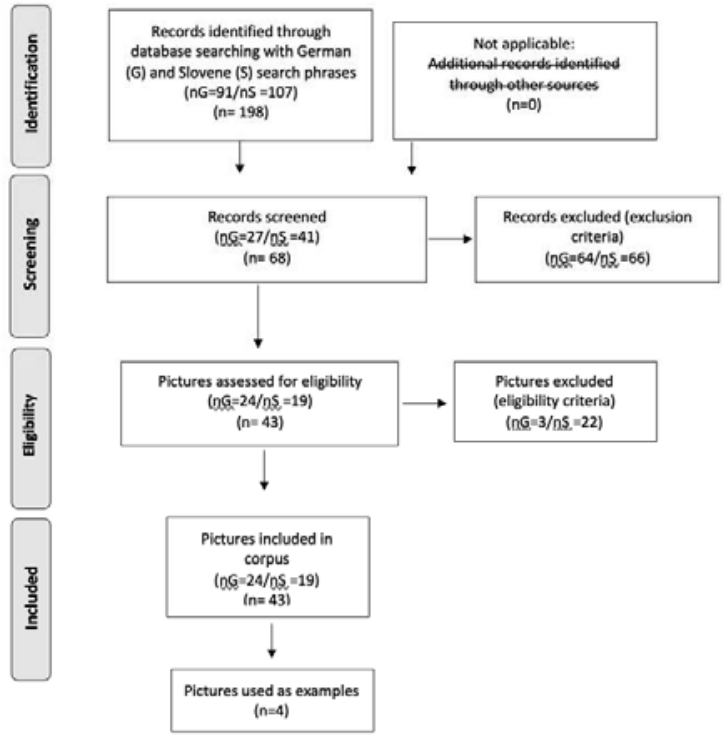

FIGURE 1. Search criteria and results.

\section{Analysis: In the Limelight?}

As outlined above, the focus of this analysis will lie on the physical visibility, positionality and agency of the individuals serving as interpreters/mediators in these photographs.

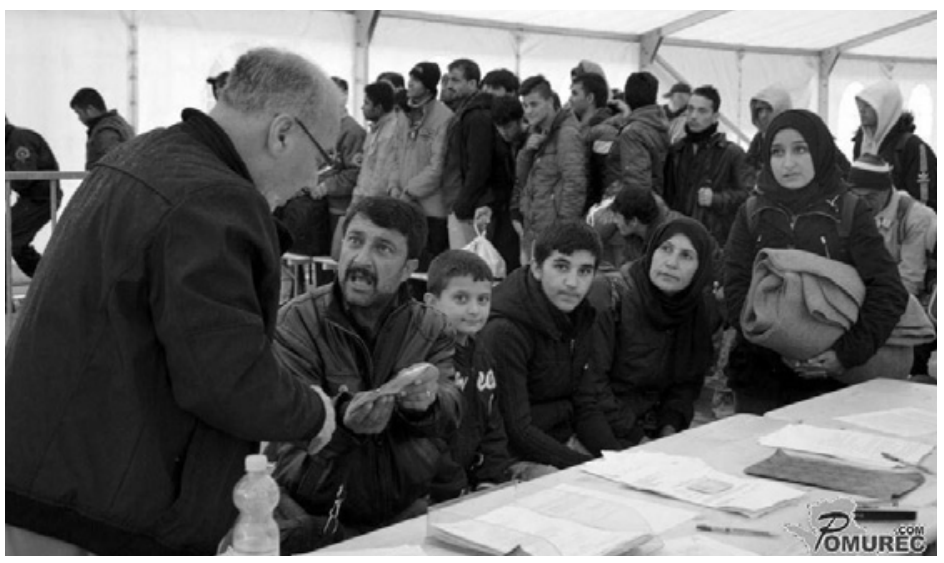

FIgure 2. Helping with registration. (ㄷ Pomurec.com)

This photograph was published on the online portal Pomurec.com on 17 October 2015 (N.N. 2015). It appeared as part of a series of photographs that were taken in the border town of Petišovci and at the Dolga vas border crossing; the photographer is not credited. The article describes the registration of refugees, and in connection with this the interpreter (the man with glasses in the black jacket and brown trousers) is briefly mentioned. His role in the registration process is also clear from the photograph, in which a migrant shows his document to the interpreter. 
The physical visibility of the interpreter for the migrants and other people at the location was based solely on his positioning; other photos published in the article indicate that officials were sitting on the other side of the table. It can thus be concluded that the man functioned as an interpreter between the officials and the refugees during the registration process. It is evident from the photograph that the interpreter was not wearing a vest with the label "interpreter". The angle from which the photograph was taken does not allow viewers to determine whether he wore any other kind of visible external designation (e.g., a badge) indicating his function. The photograph was not given a caption or further commented upon; therefore, the interpreter was not clearly identifiable as such for readers of the online portal.

Unlike in conference interpreting at high-level political meetings, for example, where the primary interlocutors often exclusively maintain eye contact with one another (Kalverkämper 2008, 145), here the refugee holding the documents explicitly turns physically towards the interpreter. The police officer or border official, for whom the refugee's statement is being interpreted, is not shown in the photograph. The aforementioned eye contact suggests that at this point the official was not directly involved in the conversation. Instead, it can be presumed that the interpreter was clarifying a specific matter with the refugee, which he then (possibly) rendered for the official, perhaps in a summarized form. Thus, in the framework of interactional visibility, the interpreter in the photograph appears to adopt an active, engaged role, possibly also seeking to help the man with whom he speaks. In the photographed moment, the interpreter and the migrant have eye contact exclusively with each other and are disregarding the official. Perhaps the interpreter also served as "principal" (Wadensjö 1998, 88), asking the refugee for clarification without having been asked to do so by the official. Thus, the act of interpreting may also have a political dimension, which is further emphasized by the fact that the interpreter works while standing; a certain position of power can thus be ascribed to him also. The interpreter's social visibility in this case is low. The photograph was not provided with any further detailed commentary, nor was it captioned.

The photograph in Figure 3 published on the Slovene online news portal 24ur.com on 21 October 2015 (S.S., K.H. and STA 2015). It was taken at the railway station in Središče ob

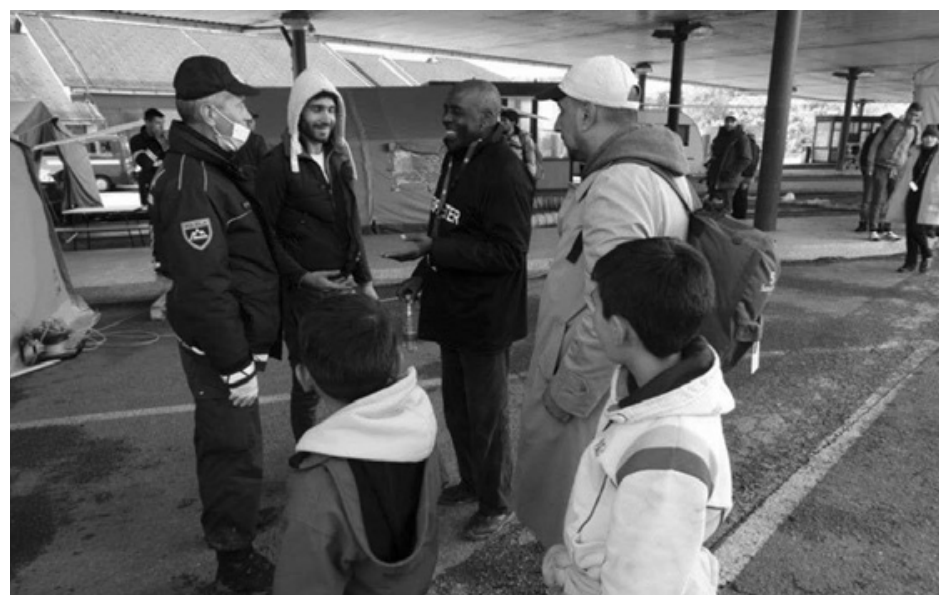

FIgURE 3. Being friendly. (@ Slovenska policija) 
Dravi, and the Slovene police are credited as the author of the photograph. The photograph appears in an article along with 16 other photographs, all of which are provided with the caption Police offccers in Središce ob Dravi.

The man in the black jacket with "Interpreter" written in white letters on it can easily be identified as the interpreter. This ensured the interpreter's physical visibility for both the migrants and other people at the location, as well as for readers of the article.

With respect to the degree of interactional agency adopted by the interpreter, the interpreter is very present and very visible in the centre of this photograph. He seems to be friendly or joking, although it is unclear whether with the police officer or the other man who stands smiling between the police officer and the interpreter, though clearly not with the family standing to the left of the interpreter. The hand gestures used by the interpreter and the man in the middle of the photograph suggest that they might be the main interactants at this precise moment. From the interpreter's positioning, which is a triangular, equidistant arrangement between interpreter, police official, and the interlocutor to the interpreter's right, and the direction he faces, one can speculatively deduce that he is not primarily focused on mediating between the family to his left, who are more in the role of passive bystanders, and the official. From the interpreter's posture, it is evident that he is turned solely to the police officer and the other man at the centre of the interactional triangle, thereby adopting the role of a "positioned interpreter" (Kalverkämper 2008, 118) to the communication partners. The man with the two children at his left is standing aside, at a distance from the conversation zone, as if he were not part of the conversation. It can also be presumed that in this conversation with the police officer, the interpreter is trying to clarify something for the man with the two children, but his proxemic posture possibly indicates a hierarchical relationship and thus suggests that the interpreter is clarifying a specific matter with the police officer without directly involving the migrant and his children (see also Tryuk 2017, 191, who suggests that it is unrealistic to expect that interpreters will not align with officials if they are positioned near them when interpreting). It could also be assumed that the interpreter is an official police interpreter, which might again have an influence on his loyalty towards his employer (police) and his other client(s). The interpreter in this photograph is not socially recognized in his function as interpreter at all: he is not mentioned, either in the text or in the caption.

The photograph in Figure 4 was published on 04 April 2017 in the online version of the Austrian daily Kurier, under the heading "Asylum and Police: 24.6 million euro for interpreters" (Wammerl 2017). The caption reads: "With the refugee crisis, costs for interpreters increased"; the photographer's name is available if one clicks on a separate information button. The article itself addresses the high overall costs for interpreters in the wake of the refugee crisis, and very negatively links it with "crime rates among foreigners" and a "communication problem". The first sentences set the tone for the remainder of the article: "The refugee crisis and a crime rate of almost $40 \%$ among foreigners confronts Austrian authorities with a massive communication problem". The photograph was also used some time after it was presumably taken at the Austrian/Slovene border to illustrate what is said in this article.

The interpreter is clearly physically visible by the bright orange vest he wears, showing the word Translator and its Arabic translation. He is shown in interaction with a group of male 


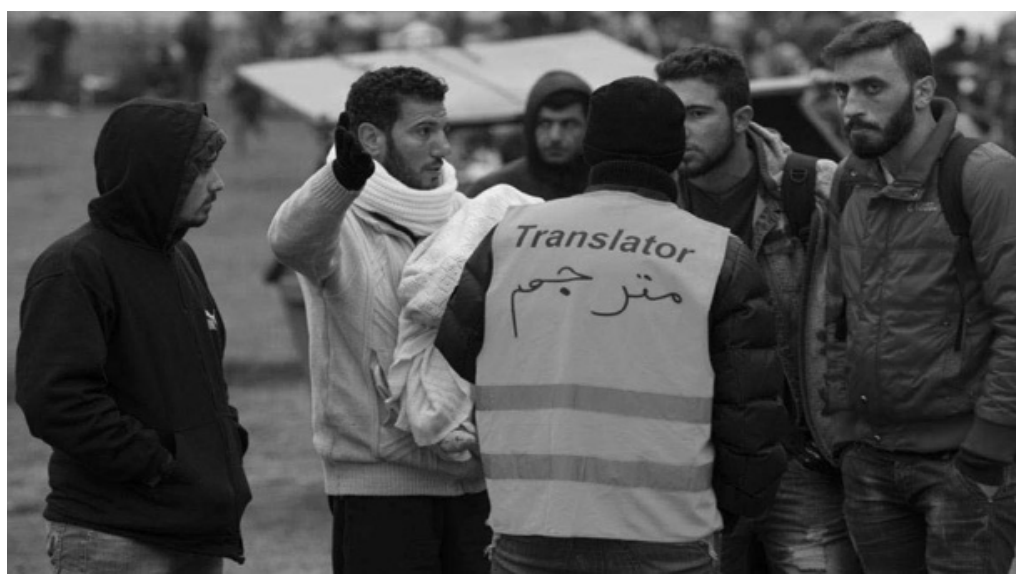

FIgURE 4. The translator. (C) Sebastian Kahnert/dpa/picturedesk.com)

persons who, for the average reader, will most probably be identifiable as foreigners through their physical appearance. And though the photograph does not explicitly say so, a reader so-inclined will most probably link the individuals shown in the photograph with the biased portrayal of foreign nationals that dominates the entire article. The interpreter himself is shown only from behind, and his physical posture is one of attentive listening. The fact that he seems to bury his hands in the pockets of his vest may be interpreted either as a touch of reserve or simply as a strategy to protect himself from the cold, since the others' posture also suggests that this was a cold spring day. It appears that one man in this group of men, which is a small sub-group within a larger group of people that is faintly visible in the background of the photograph, is the main speaker, with a hand gesture that could be negatively interpreted as imperious. And though the interpreter does not seem to be overly active at this given moment, his interactional visibility is still distinct: he is shown in a group of individuals, possibly his fellow nationals, although this cannot be proven through the accompanying text, nor assumed based on his appearance, as he is shown only from behind, and he is at the centre of the group and attention. There is no other party visible for whom he interprets, so he seems to act in a production role as the principal, providing information on his own. The interpreter's social visibility and recognition are very low in this case, owing to the tone of the article. At the end of the text he is indirectly outed as a "lay interpreter" - which will most probably be the case, since there was hardly any training available for interpreters for languages such as Arabic or Dari/Farsi, which were much needed in the period when the photographs were taken. The text $\mathrm{u}$ ses a quotation from a representative of the Austrian Court Interpreters Association to negatively juxtapose the use of lay interpreters with the use of court interpreters: "The police often use lay interpreters. These are for instance taxi drivers with good language skills. But the responsibility is extremely high". And while the use of lay interpreters is indeed problematic, the way this quotation is used in the text seems to reflect a certain degree of reservation on the part of established groups of interpreters towards newcomers, even if they are needed for specific languages when no trained interpreters are available for certain language combinations. 


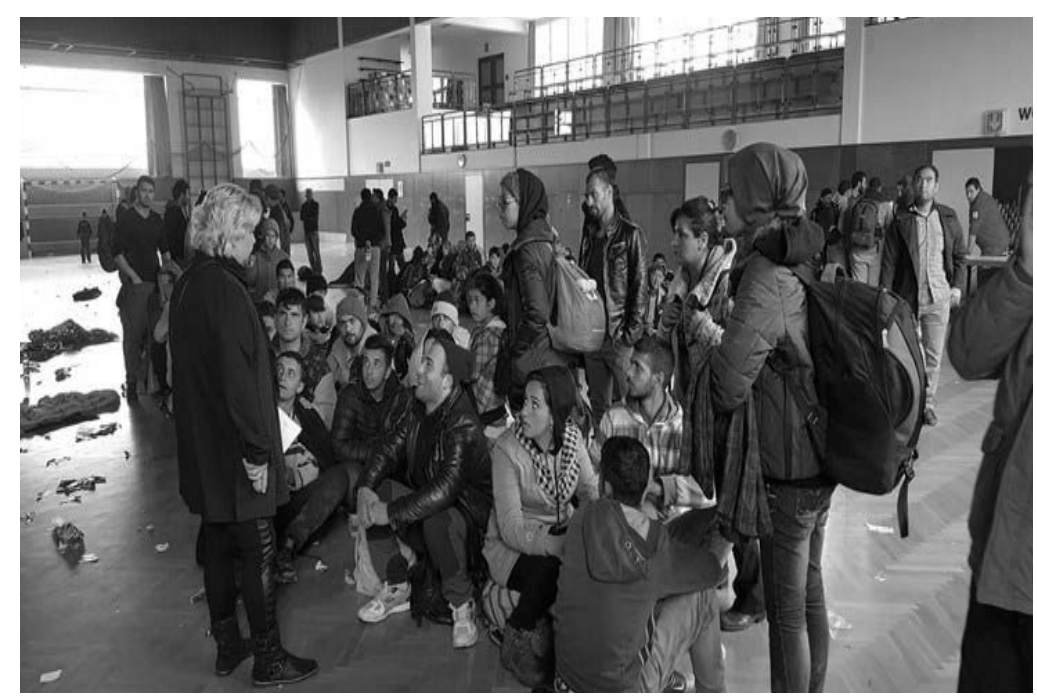

Figure 5. Moni. (C Dieter Schmidt)

The photograph in Figure 5 was was published on 23 October 2015 in both the print and online version of an article in the Austrian daily Der Standard, together with two other photographs (Schmidt 2015). Both the author's name and the photographer's name are given.

In the photograph that was chosen as an example, the interpreter is referred to by her first name (Moni). She does not wear a vest or any other visible sign but is identified through the photograph's caption, which says, "Interpreter Moni explains in Farsi what will happen". This caption clearly identifies the woman standing in front of a group of refugees in a gym as the interpreter. Her role as interpreter as identifiable through this photograph is again a very active one: She is the one providing information to an entire group of people, who seem to listen attentively to what she says. Moni, who is introduced in the article as a senior citizen with a Farsi background, who has been living in Austria for a long time, again seems to be the original author of what she says; there is no other party visible whose utterances she might render. Her work is portrayed in a very positive manner, making her also socially visible. Translation is viewed as a means of preventing "panic": "Retiree Moni knows how important translation is because 'the people then know what happens to them and this prevents them from panicking"'. The article lends voice to Moni's view of interpreting, where cultural explanations are described as an integral part of her task: "We explained that people here are friendly, that they don't need to be afraid and that they will be taken to Vienna in buses[.]"

\section{Conclusion}

The analysis we present in this contribution is an attempt at describing interpreters' physical visibility, agency and positionality in transborder humanitarian interpreting, based on a visual approach that is complemented by integrating information gleaned from accompanying cotext(s). This approach could be expanded by extending the overall corpus (alternative search strings, search machines), including more examples in the analysis, and integrating additional 
interdisciplinary perspectives for visual analysis. It might also be interesting to pay closer attention to the differences in the portrayal of interpreters in Austrian and Slovene media against a background of different political and sociocultural parameters.

The situational and interactional context shown in the photographs we chose underlines the established fact that this was not an ordinary context, but that the overall circumstances were extraordinary and offered specific challenges for an yone in volved in these situations, interpreters and others. Physically, interpreters were more visible in a greater number of photographs than we had originally expected. In this respect, it might be interesting to see whether their media visibility has indeed changed in view of these circumstances: just as many refugees were only paid attention and only obtained real visibility when they arrived in Europe in larger numbers, interpreters only seem to have obtained greater visibility because of this situation and because they were suddenly needed in larger numbers.

Their positionality as interpreters, often wrongly but typically for media reports labelled as translators, was indicated in the photographs by visible signs such as badges or vests, but also by their presence and posture in a specific interactional space. What could also be deduced, not unexpectedly, from the situations shown in the photographs under review, was that the other interactants accepted, or perhaps even expected, a high(er) degree of interactional agency (visibility) which seems to support our initial hypothesis. What we cannot deduce for sure from the photographs is whether the interpreters offered their services as volunteers or were officially ap pointed, th ough, as far as we can tell from the accompanying texts, some of them will not have received prior training in interpreting, though some seem to have had long-term experience. This volunteering perspective and interpreters' positionality as volunteer-interpreters are visible in the active attempt by many of the interpreters in these photographs to help, assist and even comfort and reassure, as explained in some of the co-texts. And even though the mediators shown in these photographs are presented as translators, as a common umbrella term for translation and interpreting, the situations in which they were precipitated would most probably not always have involved interpreting proper but rather a form of explaining matters to (larger) groups of individuals; if institutional representatives are shown, they are mostly shown in a less active, waiting position, while the interpreters are at the centre of the photographs and apparently the attention. Yet, even though interpreters may have been in the limelight, at least in some of these situations, for some moments and in this set of photographs, their agency and positionality are not comprehensively recognized, in the sense of social recognition and visibility, at least not in the small sample of photographs that was chosen for this analysis. While some of the accompanying texts positively, and sometimes quite warmly, recognize their important position as mediators amidst a challenging and chaotic situation, others fail to acknowledge their presence or function at all, even though large sums of money were invested in paying for interpreting services (Bergunde and Pöllabauer 2019, 1-2).

There are also limitations to our approach that we would like to address: We drew assumptions on a visual basis and on additional co-texts only, and cannot corroborate our suppositions about the interpreters' agency or the assumed relations in the photographs, since we lack information on their background and biography, and on whether they are interpreters or 
intercultural mediators, except for what is stated in the accompanying co-texts. In some cases, additional research and sleuthing might turn up additional personal information; in other cases, it might not be possible to identify the persons in the photographs and get in touch with them. It might, however, be a valuable additional perspective for similar research, or even a follow-up study, to have interpreters retrospectively analyse their positioning and the associated challenges.

In spite of these limitations, and while the corpus we have chosen for this contribution allows only a small glimpse into interpreting in action in a particular interactional space, we nonetheless think that working with pictures may help to shed light on the interactional agency of interpreters, and it is hoped that other studies will also attempt to address issues of interpreters' positionality through a visual approach. This leaves us to conclude this contribution with a question that might be addressed in more depth in the future: If, as Brighenti holds $(2007,330)$, “[d]istortions in visibility lead to distortions in social representations", what does this mean for the agency and positionality of interpreters?

\section{References}

Angelelli, Claudia. 2004a. Medical Interpreting and Cross-cultural Communication. Cambridge: Cambridge University Press.

- 2004b. Revisiting the Interpreter's Role: A Study of Conference, Court, and Medical Interpreters in Canada, Mexico, and the United States. Amsterdam: John Benjamins.

Baigorri-Jalón, Jesús. 2016. "The Use of Photographs as Historical Sources, a Case Study. Early Simultaneous Interpreting at the United Nations." In New Insights in the History of Interpreting, edited by Kayoko Takeda and Jesús Baigorri-Jalón, 167-92. Amsterdam: John Benjamins.

Barsky, Robert F. 1996. “The Interpreter as Intercultural Agent in Convention Refugee Hearings.” The Translator 2 (1): 45-63. https://doi.org/10.1080/13556509.1996.10798963.

Bergunde, Annika, and Sonja Pöllabauer. 2019. "Curricular Design and Implementation of a Training Course for Interpreters in an Asylum Context.” Translation and Interpreting 11 (1): 1-21.

Breckner, Roswitha. 2010. Sozialtheorie des Bildes. Zur interpretativen Analyse von Bildern und Fotografien. Bielefeld: Transcript.

Brighenti, Andrea. 2007. "Visibility. A Category for the Social Sciences." Current Sociology 55 (3): 323-42. https://doi.org/10.1177/0011392107076079.

Camayd-Freixas, Erik. 2013. "Court Interpreter Ethics and the Role of Professional Organizations." In Interpreting in a Changing Landscape. Selected Papers from Critical Link 6, edited by Christina Schäffner, Kredens Krzysztof, and Yvonne Fowler, 15-30. Amsterdam: John Benjamins.

Cemerin, Vedrana. 2019. "Language Mediation in Emergency Migration Contexts: A Case Study of the Migrant Crisis 2015 in Croatia." In Intercultural Crisis Communication. Translation, Interpreting and Languages in Local Crises, edited by Christophe Declercq and Federico M. Federici, 39-62. London: Bloomsbury.

Declercq, Christophe, and Federico M. Federici, eds. 2019. Intercultural Crisis Communication. Translation, Interpreting and Languages in Local Crises. London: Bloomsbury.

Delgado Luchner, Carmen, and Leilla Kherbiche. 2018. "Without Fear or Favour? The Positionality of ICRC and UNHCR Interpreters in the Humanitarian Field.” Target 30 (3): 415-38. https://doi.org /10.1075/target.17108.del.

Diriker, Ebru. 2004. De-/Re-contextualizing Conference Interpreting: Interpreters in the Ivory Tower? Amsterdam: John Benjamins.

Federici, Federico. 2020. “'Language barrier' in UK newspapers 2010-2020: Figurative Meaning, Migration and Language Needs." Cultus 13: 194-219. 
Fernández-Ocampo, Anxo, and Michaela Wolf. 2014a. “Framing the Interpreter's Wife.” In Framing the Interpreter. Towards a Visual Perspective, edited by Anxo Fernández-Ocampo and Michaela Wolf, 72-82. London: Routledge.

Fernández-Ocampo, Anxo, and Michaela Wolf, eds. 2014b. Framing the Interpreter. Towards a Visual Perspective. London: Routledge.

Harrington, Frank J. 2004. "Book Rreviews. Melanie Metzger. Sign Language Interpreting: Deconstructing the Myth of Neutrality." Interpreting 6 (1): 109-16.

Kadrić, Mira. [in print]. "Formung einer Translationskultur im DACH-Raum.” In Entwicklungslinien des Dolmetschens im soziokulturellen Kontext. Translationskultur(en) im DACH-Raum, edited by Sonja Pöllabauer and Mira Kadrić. Tübingen: Narr Francke Attempto.

Kalverkämper, Hartwig. 2008. “Der kommunikative Körper in Dolmetschprozessen.” In Translationskultur-ein innovatives und produktives Konzept, edited by Larisa Schippel, 71-165. Berlin: Frank \& Timme.

Kinnunen, Tuija, and Kaisa Koskinen, eds. 2010. Translators' Agency. Tampere: Tampere University Press.

Martínez-Gómez, Aída. 2015. "Invisible, Visible or Everywhere in Between? Perceptions and Actual Behaviours of Non-Professional Interpreters and Interpreting Users." The Interpreters' Newsletter 20: 179-94.

Metzger, Melanie. 1999. Sign Language Interpreting. Deconstructing the Myth of Neutrality. Washington, DC: Gallaudet University Press.

Mitchell, W.J. Thomas. 1992. "The Pictorial Turn.” Art Forum (March): 89-95.

Moher, David, Alessandro Liberati, Jennifer Tetzlaff, and Douglas G. Altman for the PRISMA Group. 2009. "Preferred Reporting Items for Systematic Reviews and Meta-Analyses: The PRISMA Statement.” PLoS Med 6 (7): e1000097. https://doi.org/10.1371/journal.pmed1000097.

Mokre, Monika. 2015. Solidarität als Übersetzung: Wien: Transversal Texts.

Morel, Alenka, and Vojko Gorjanc. 2016. Skupnostno tolmačenje: slovenščina v medkulturni komunikaciji. Ljubljana: Znanstvena založba Filozofske fakultete.

N. N. 2015. "Prvi begunci iz Petisovec in Dolge vasi že na poti proti Šentilju." Pomurec.com, October 17, 2015. https://www.pomurec.com/vsebina/35537/FOTO_Prvi_begunci_iz_Petisovec_in_Dolge_vasi _ze_na_poti_proti_Sentilju\#1.

Piróth, Attila, and Mona Baker. 2019. The Ethics of Volunteerism in Translation. Translators Without Borders and the Platform Economy. Accessed January 25, 2021. http://www.pirothattila.com/Piroth-Baker_The _Ethics_of_Volunteerism_in_Translation.pdf.

Pišek, Mojca, and Maja Šučur. 2016. "Prevajalci med begunsko krizo: so prestopili mejo pristojnosti?" Dnevnik, March 17, 2016. https://www.dnevnik.si/1042732054.

Pokorn, Nike K. 2020. "Introduction: Why This Book and How to Use It." In Teacher Education for Community Interpreting and Intercultural Mediation: Selected Chapters, edited by Nike K. Pokorn, Maurizio Viezzi, and Tatjana Radanović Felberg, 6-16. Ljubljana: Ljubljana University Press.

Pokorn, Nike K., and Tamara Mikolič Južnič. 2020. "Community Interpreters versus Intercultural Mediators. Is It Really All about Ethics?” In Ethics of Non-Professional Translation and Interpreting. [Special Issue of Translation and Interpreting Studies 15, no. 1], edited by Esther Monzó-Nebot and Melissa Wallace, 80-107. Amsterdam: John Benjamins.

Pokorn, Nike K., Simos Grammenidis, Anthi Wiedenmayer, Maurizio Viezzi, Caterina Falbo, Antonio Chiarenza, Anna Ciannameo, Tatjana Radanović Felberg, Hanne Skaaden, Uršula Lipovec Čebron, Juš Škraban, and Nataša Hirci. 2020. "The Profiles of a Community Interpreter and of an Intercultural Mediator in Greece, Italy, Norway and Slovenia." In Teacher Education for Community Interpreting and Intercultural Mediation: Selected Chapters, edited by Nike K. Pokorn, Maurizio Viezzi, and Tatjana Radanović Felberg, 18-45. Ljubljana: Ljubljana University Press.

Pokorn, Nike K., and Jaka Čibej. 2018a. "'Do I Want to Learn a Language Spoken by Two Million People?' Mediation Choices by Mid-Term and Long-Term Migrants.” Language Problems and Language Planning 42 (3): 288-307. https://doi.org/10.1075/lplp.00025.pok.

—. 2018b. “'It's So Vital to Learn Slovene.' Mediation Choices by Asylum Seekers in Slovenia." Language Problems and Language Planning 42 (3): 307-27. https://doi.org/10.1075/lplp.00024.pok. 
Pöllabauer, Sonja, and Iris Topolovec. 2020. "Ethics in Public Service Interpreting." In The Routledge Handbook of Translation and Ethics, edited by Kaisa Koskinen and Nike K. Pokorn, 211-26. London: Routledge.

Pöllabauer, Sonja. 2015. “Role.” In Routledge Encyclopedia of Interpreting Studies, edited by Franz Pöchhacker, with Nadja Grbić, Peter Mead, and Robin Setton, 355-60. London: Routledge.

Prunč, Erich. 2012. Entwicklungslinien der Translationswissenschaft. Berlin: Frank \& Timme.

—. 2017. "Auf der Suche nach Aschenbrödels Schuh. Ethische Perspektiven des Kommunaldolmetschens." In Interpreting Studies at the Crossroads of Disciplines, edited by Simon Zupan and Aleksandra Nuč, 21-42. Berlin: Frank \& Timme.

Roy, Cynthia. 1993. "The Problem with Definitions, Descriptions, and the Role Metaphors of Interpreters." Journal of Interpretation 6 (1): 127-54.

Rudvin, Mette, and Astrid Carfagnini. 2020. "Interpreting Distress Narratives in Italian Reception Centres: The Need for Caution when Negotiating Empathy." Cultus 13: 123-44.

Ruiz Rosendo, Lucía. 2020. "Translation and Interpreting in Conflict." In The Oxford Handbook of Translation and Social Practices, edited by Meng Ji and Sara Laviosa. https://doi.org/10.1093/oxfordhb /9780190067205.013.24.

S.S., K.H. and STA. 2015. "Ena od begunk pri Župelevcu rodila kar na poti. V Brežicah in Dobovi okoli 3000 novih beguncev." 24ur.com, October 21, 2015. https://www.24ur.com/novice/slovenija/video -begunci-izcrpani-kljub-mrazu-zaspali-na-tleh-pod-milim-nebom.html.

Schmidt, Colette M. 2015. "Schreckensbilder kann ich keine teilen." Der Standard, October 23, 2015. https:/www.derstandard.at/story/2000024428331/stadtchef-von-wagna-schreckensbilder-kann-ich -keine-teilen.

Takeda, Kayoko. 2014. "The Visibility of Collaborators. Snapshots of Wartime and Post-War Interpreters." In Framing the Interpreter. Towards a Visual Perspective, edited by Anxo Fernández-Ocampo and Michaela Wolf, 150-59. London: Routledge.

Thomas, Tanja, Elke Grittmann, Kaya de Wolf, and Lina Brink. 2017. "Anerkennung und Sichtbarkeit in gegenwärtigen Medienkulturen.” In Anerkennung und Sichtbarkeit. Perspektiven für eine kritische Medienkulturforschung, edited by Tanja Thomas, Lina Brink, Elke Grittmann, and Kaya de Wolff, 11-21. Bielefeld: Transcript.

Todorova, Marija. 2017. "Interpreting at the Border: 'Shuttle Interpreting' for the UNHCR." CLINA: An Interdisciplinary Journal of Translation, Interpreting and Intercultural Communication 3 (2): 115-29. https://doi.org/10.14201/clina201732115129.

—. 2020. "Interpreting for Refugees. Lessons Learned from the Field." In Interpreting in Legal and Healthcare Settings. Perspectives on Research and Training, edited by Eva N. S. Ng and Ineke H. M. Crezee, 63-81. Amsterdam and Philadelphia: John Benjamins.

Torikai, Kumiko. 2009. Voices of the Invisible Presence: Diplomatic Interpreters in Post-World-War II Japan. Amsterdam: John Benjamins.

Torresi, Ira. 2017. "Seeing Brokering in Bright Colours. Participatory Artwork Elicitation in CLB Research." In Non-Professional Interpreting and Translation: State of the Art and Future of an Emerging Field of Research, edited by Rachele Antonini, Letizia Cirillo, Linda Rossato, and Ira Torresi, 337-57. Amsterdam: John Benjamins.

Translators without Borders. 2017a. Research Report. Lost for Words. Improving Information Access for Refugees and Migrants in Greece. Accessed February 1, 2021. https://translatorswithoutborders.org/wp -content/uploads/2017/04/Lost-for-Words.pdf.

- 2017b. Research Report. Putting Language on the Map in the European Refugee Response. Accessed February 1, 2021. https://translatorswithoutborders.org/putting-language-on-the-map-in-the -european-refugee-response/.

Tryuk, Małgorzata. 2017. "Conflict. Tension. Aggression. Ethical Issues in Interpreted Asylum Hearings at the Office for Foreigners in Warsaw." In Ideology, Ethics and Policy Development in Public Service Interpreting and Translation, edited by Carmen Valero-Garcés and Rebecca Tipton, 179-94. Bristol Blue Ridge Summit: Multilingual Matters.

UNHCR, ed. 2015. Trainingshandbuch für DolmetscherInnen im Asylverfahren. Linz: Trauner. 
-. 2018. Handbook for Interpreters in Asylum Procedures. Berlin: Frank \& Timme.

UNHCR. 2016. Global Trends. Forced Displacement in 2015. Geneva: UNHCR.

Venuti, Lawrence. 2008. The Translator's Invisibility. A History of Translation. 2nd ed. London: Routledge.

Wadensjö, Cecilia. 1998. Interpreting as Interaction. London: Longman.

Wagner, David. 2017. "Dolmetschen für Train of Hope." MA Thesis, University of Vienna.

Wallace, Melissa, and Carlos Iván Hernández. 2017. "Language Access for Asylum Seekers in Borderland Detention Centers in Texas." Revista de Llengua i Dret, Journal of Language and Law 68: 143-56. https://doi.org/10.2436/rld.i68.2017.2940.

Wammerl, Patrick. 2017. "Asyl und Polizei: 24,6 Millionen Euro für Dolmetscher." Kurier, April 4, 2017. https://kurier.at/chronik/oesterreich/asyl-und-polizei-24-6-millionen-euro-fuer-dolmetscher/256.116 .554 .

Wolf, Michaela, and Anxo Fernández-Ocampo. 2014. "Framing the Interpreter." In Framing the Interpreter. Towards a Visual Perspective, edited by Anxo Fernández-Ocampo and Michaela Wolf, 1-16. London: Routledge.

Zhan, Cheng, and Lishang Zeng. 2017. "Chinese Medical Interpreters' Visibility through Text Ownership: An Empirical Study on Interpreted Dialogues at a Hospital in Guangzhou." Interpreting 19 (1): 98-118. https://doi.org/10.1075/intp.19.1.05zha.

Zimányi, Krisztina. 2015. "Reflections on Interpreting Settings and Ethics in View of Visual Representations of la Malinche." Translation \& Interpreting 7 (2): 1-16.

Zwischenberger, Cornelia. 2009. "Conference Interpreters and Their Self-Representation: A Worldwide Web-Based Survey." Translation and Interpreting Studies 4 (2): 239-53. https://doi.org/10.1075/tis.4.2 .08 zwi. 